\title{
Impact of cytomegalovirus infection on B cell differentiation and cytokine production in multiple sclerosis
}

Ana Zabalza ${ }^{1,2}$, Andrea Vera $^{1}$, Elisenda Alari-Pahissa ${ }^{3}$, Elvira Munteis ${ }^{1}$, Antía Moreira ${ }^{1,4}$, Jose Yélamos ${ }^{5,6}$, Mireia Llop ${ }^{1}$, Miguel López-Botet ${ }^{3,5,6}$ and Jose E. Martínez-Rodríguez ${ }^{*^{*}}$ (1)

\begin{abstract}
Background: Human cytomegalovirus (HCMV) infection has been recently associated with a low risk of multiple sclerosis (MS), yet the basis behind this observation remains uncertain. In this study, we aimed to determine in MS patients whether HCMV induces modifications in the peripheral B cell compartment.

Methods: HCMV serostatus was determined in 73 MS patients (55 relapsing-remitting MS (RRMS); 18 progressive MS (PMS)) and 30 healthy controls, assessing their B cell immunophenotype and cytokine production (GM-CSF, IL-6, IL-10, and TNFa) by flow cytometry.

Results: HCMV seropositivity in untreated MS patients $(n=45)$ was associated with reduced switched memory B cells, contrasting with an opposite effect in PMS. Expansions of transitional B cells were observed in HCMV $(+)$ IFN $\beta$ treated RRMS patients but not in HCMV $(-)$ cases $(p<0.01)$, suggesting that HCMV may influence the distribution of $B$ cell subsets modulating the effects of IFN $\beta$. Considering the B cell functional profile, HCMV(-) PMS displayed an increased secretion of proinflammatory cytokines (IL-6, TNFa) as compared to HCMV(+) PMS and RRMS cases $(p<0.001)$.

Conclusions: Our study reveals an influence of HCMV infection on the phenotype and function of B cells, promoting early differentiation stages in RRMS and reducing the proinflammatory cytokine profile in advanced MS forms, which might be related with the putative protective role of this virus in MS.
\end{abstract}

Keywords: Multiple sclerosis, B cells, Human cytomegalovirus, Interferon-beta

\section{Introduction}

Multiple sclerosis (MS) is a demyelinating disease of the central nervous system classically considered to be mediated by T cells. A relevant role of B cells in MS pathogenesis is supported by a growing body of evidences, particularly the successful therapeutic results using antiCD20 monoclonal antibodies [1, 2]. Epstein-Barr virus (EBV), the main pathogen related to MS [3], establishes a persistent infection having memory $B$ cells as the main

\footnotetext{
* Correspondence: JMartinezR@hospitaldelmar.cat

${ }^{1}$ Neurology Department, Hospital del Mar Medical Research Institute (IMIM), Passeig Marítim, 25-29, 08003 Barcelona, Spain

Full list of author information is available at the end of the article
}

reservoir. In this regard, it is conceivable that efficacy of anti-CD20 therapies might depend not only on suppression of $\mathrm{B}$ cell functions, but also on the control of EBV infection [4]. On the other hand, human cytomegalovirus (HCMV) has been associated with a lower MS susceptibility based on seroepidemiological studies $[5,6]$, yet the basis for these observations remains poorly understood.

HCMV chronic infection leads to marked changes in the immune system [7], mainly characterized by the differentiation and expansion of specific $\mathrm{T}$ cells [8] and adaptive NK cell subsets expressing the CD94/NKG2C activating receptor [9], a phenotypic feature that has been associated with reduced MS progression [10]. In

(c) The Author(s). 2020 Open Access This article is licensed under a Creative Commons Attribution 4.0 International License, which permits use, sharing, adaptation, distribution and reproduction in any medium or format, as long as you give appropriate credit to the original author(s) and the source, provide a link to the Creative Commons licence, and indicate if changes were made. The images or other third party material in this article are included in the article's Creative Commons licence, unless indicated otherwise in a credit line to the material. If material is not included in the article's Creative Commons licence and your intended use is not permitted by statutory regulation or exceeds the permitted use, you will need to obtain permission directly from the copyright holder. To view a copy of this licence, visit http://creativecommons.org/licenses/by/4.0/ The Creative Commons Public Domain Dedication waiver (http://creativecommons.org/publicdomain/zero/1.0/) applies to the data made available in this article, unless otherwise stated in a credit line to the data. 
this study, we evaluated whether HCMV may have an influence on the B cell compartment in MS patients according to clinical features of the disease.

\section{Methods \\ Samples}

Blood was collected from healthy controls (HC) and MS patients fulfilling McDonald criteria 2017 at the Neurology Department, Hospital del Mar, Barcelona (Spain), excluding cases with relapses or corticosteroid treatment in the previous 30 days, severe concomitant disease, pregnancy, and disease-modifying therapies known to deplete peripheral lymphocytes or alter their trafficking. MS forms were defined as relapsing-remitting MS (RRMS) and progressive MS (PMS) [11].

\section{Herpesvirus serostatus}

Standard serological diagnostic tests were performed to evaluate EBV-(LIASON ${ }^{\circ}$ ) and HCMV-specific antibodies (Roche ${ }^{\circ}$, Cobas602).

\section{B cell immunophenotype}

Peripheral blood mononuclear cells (PBMCs) isolated from blood samples using Ficoll-Hypaque density gradient centrifugation were analyzed by flow cytometry using a direct staining (Fig. 1) with the following fluorochromeconjugated monoclonal antibodies: CD19-PE-Cy7 (Invitrogen), CD38-APC, CD27-PerCP-Cy5.5 (BD Biosciences), IgD-FITC (Southern Biotech), CD10-PE (Biolegend), and DAPI (Thermo Fisher). B cell subsets were defined gating CD19+ lymphocytes as follows: plasmablasts-plasma cells (PB-PC: CD38 $\left.{ }^{\text {hi }} \mathrm{CD} 10-\right)$, transitional (TB: CD38 ${ }^{\text {hi }} \mathrm{CD} 10+$ ), naive (NB: $\mathrm{CD} 38^{\text {low/neg }} \mathrm{CD} 10-\mathrm{IgD}+\mathrm{CD} 27-$ ), unswitched memory (UMB: $\mathrm{CD} 38^{\text {low } / \text { neg }} \mathrm{CD} 10-\mathrm{IgD}+\mathrm{CD} 27+$ ), switched memory (SMB: CD38 ${ }^{\text {low } / \text { neg }} \mathrm{CD} 10-\mathrm{IgD}-\mathrm{CD} 27+$ ), and double negative (DN: CD38 ${ }^{\text {low/neg }} \mathrm{CD} 10-\mathrm{IgD}-\mathrm{CD} 27$ -). Samples were analyzed in LSR II Fortessa (BD Biosciences) using FlowJo (Tree Star) software.

\section{Functional analysis of $B$ cells}

$B$ cell cytokine production was evaluated in MS patients (RRMS, $n=45$; PMS, $n=18)$ and HC $(n=20)$ incubating PBMCs for $24 \mathrm{~h}$ with $\mathrm{CpG}(10 \mu \mathrm{g} / \mathrm{ml})$, adding in the last $4 \mathrm{~h}$ PMA $(50 \mathrm{ng} / \mathrm{mL})$ and ionomycin $(1 \mu \mathrm{g} / \mathrm{ml}$, Sigma-Aldrich), monensin (GolgiStop), and brefeldin (GolgiPlug, BD Biosciences). Samples were stained using CD19-PE-Cy7 (Invitrogen) and CD3-perCP (BD Biosciences), permeabilized, fixed, and stained with the following cytokine-specific monoclonal antibodies: anti-GMCSF-APC, anti-IL-6-FITC (Biolegend), anti-IL-10-PE (BD Biosciences), and anti-TNF $\alpha$ conjugated with the CFP fluorochrome. Samples were acquired in LSR II Fortessa and data analyzed by FlowJo software, defining the proportions of B cells stained for specific cytokines.

\section{Statistical analysis}

Kolmogorov-Smirnov test assessed normal distribution, providing means and standard deviations for parametric variables, and medians and interquartile range for nonparametric variables. Values were compared using Student's $t$ test for parametric variables or Mann-Whitney $U$ test for non-parametric, respectively. Pearson or Spearman correlation indexes were calculated for pair-wise continuous variables. Results were considered significant at the two-sided level of 0.05 . Data analysis was performed using GraphPad Prism 6.0 software (La Jolla, CA).

\section{Results}

\section{Demographic description}

We studied $30 \mathrm{HC}$ and $73 \mathrm{MS}$ patients (55 RRMS, 18 PMS: 8 secondary PMS, 10 primary PMS) (Table 1). HCMV serology distribution was comparable in controls and MS patients. No HCMV-related clinical differences were perceived, other than a lower disability score in $\mathrm{HCMV}(+)$ PMS as compared to HCMV(-) PMS patients (MSSS, $5.09 \pm 2.23$ vs.7.48 $\pm 1.28, p<0.05$ ).

\section{Distribution of $B$ cell subsets in untreated MS according to clinical forms and HCMV serology}

Assessment of the B cell immunophenotype in MS patients without treatment $(n=45)$ and in HC did not show significant differences in the distribution of the main B cell subsets (Additional file 1: Table 1). However, stratifying MS cases according to clinical form revealed that RRMS displayed lower proportions of TB cells together with increased SMB cells as compared to HC and PMS, whereas PMS had lower proportions of UMB (Fig. 2a). Interestingly, HCMV seropositivity was associated with greater proportions of NB and reduced SMB cells in RRMS, contrasting with an opposite effect in PMS (Fig. 2b). No differences in the proportions of the different subsets were noticed in HC stratified according to HCMV serology. These results suggest that HCMV infection may differently influence the B cell compartment distribution in MS depending on the clinical form.

\section{Impact of HCMV on the B cell compartment in IFN $\beta$ - treated MS patients}

IFN $\beta$ therapy in RRMS patients $(n=23)$ was associated with increased proportions of TB and NB cells, and a reciprocal reduction of UMB, SMB, and DN cells (Fig. 3a), in line with previous studies describing an effect of this cytokine on the redistribution of B cell subsets in MS patients [12]. Glatiramer acetate treatment $(n=5)$ was not associated with modifications in B cell subsets (Fig. 3a).

Remarkably, the effect of IFN $\beta$ therapy on the proportions of TB cells differed according to HCMV serostatus, observing an increase in treated $\mathrm{HCMV}(+)$ MS patients but not in seronegative cases (Fig. 3b). Moreover, IFN $\beta$ 


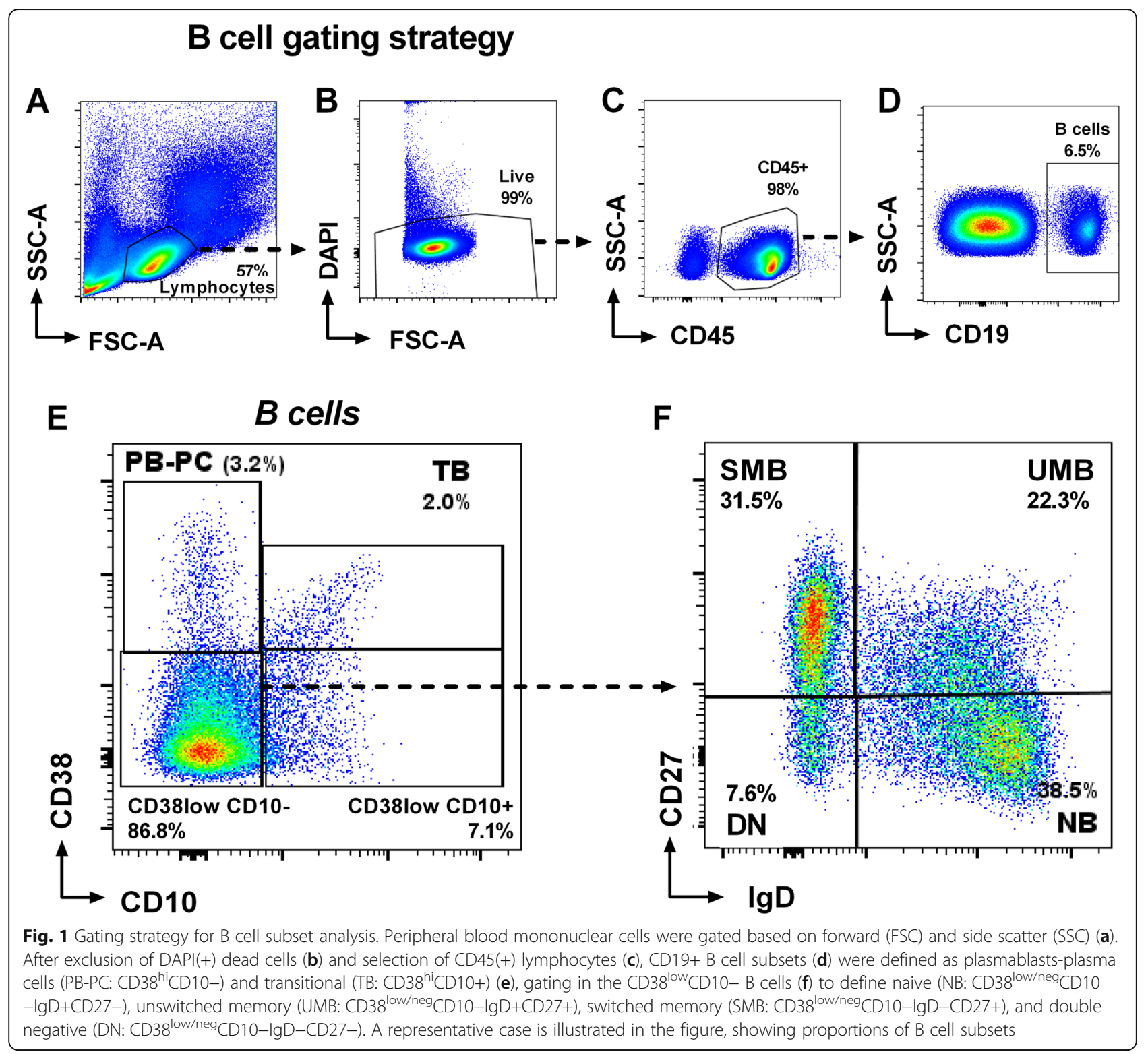

therapy in $\mathrm{HCMV}(-)$ RRMS was associated with increased NB and reduced SMB cells, resembling the effect of HCMV infection on these B cell subsets described above, which dampened the differences with $\operatorname{HCMV}(+)$ treated cases (Fig. 3b). These results revealed that HCMV infection may influence the distribution of B cell subsets in MS patients modulating the effects of IFN $\beta$.

Functional implications of HCMV on the cytokine profile of $\mathrm{B}$ cells in MS

$B$ cell cytokine production was evaluated as described in the "Methods" section (Fig. 4a). No differences were found between $\mathrm{HC}$ and the whole group of MS patients, though we observed a greater IL-10 secretion by B cells from RRMS and PMS patients as compared to $\mathrm{HC}$, and increased GM-CSF by B cells from PMS as compared to RRMS patients (Fig. 4b). Considering B cell subsets, IL10 production in MS was directly related to proportions of TB cells $(R 0.35, p<0.05)$ and inversely to SMB cells $(R-0.39, p<0.05)$, whereas TNF $\alpha$ appeared inversely related to TB $(R-0.43, p<0.01)$ and directly to UMB $(R$ 0.49, $p<0.01)$. IFN $\beta$ therapy, age, and disability scores appeared unrelated with the B cell cytokine production (data not shown). On the other hand, $\operatorname{HCMV}(-)$ PMS displayed greater IL- 6 and TNF $\alpha$ production as compared to $\operatorname{HCMV}(+)$ PMS and HCMV(-) RRMS patients, contrasting with comparable values of cytokine production in $\mathrm{HCMV}(+)$ cases (Fig. 4c). These results suggest that HCMV infection in PMS patients may decrease the production of proinflammatory cytokines by B cells. 
Table 1 Demographic and clinical characteristics of MS patients and controls

\begin{tabular}{|c|c|c|c|c|c|c|c|}
\hline \multirow{2}{*}{\multicolumn{2}{|c|}{ Age, years (mean $\pm S D$ ) }} & $\mathrm{HC}(n=30)$ & RRMS $(n=55)$ & $\operatorname{PMS}(n=18)$ & $p$ value, $\mathrm{HC}$ vs MS & $p$ value, RRMS vs PMS & $p$ value, RRMS vs $\mathrm{HC}$ \\
\hline & & $41.1 \pm 11.4$ & $44.7 \pm 12.1$ & $60.1 \pm 8.0$ & $<0.01$ & $<0.01$ & 0.190 \\
\hline \multicolumn{2}{|c|}{ Female sex, $n(\%)$} & $18(60.0 \%)$ & $31(56.40 \%)$ & $11(61.10 \%)$ & 0.498 & 0.914 & 0.173 \\
\hline \multicolumn{2}{|c|}{ HCMV(+) serology, n (\%) } & $23(76.7 \%)$ & $35(63.6 \%)$ & $11(61.1 \%)$ & 0.133 & 0.400 & 0.093 \\
\hline \multicolumn{2}{|c|}{ EBV(+) serology, $n(\%)$} & $24(85.7 \%)$ & $54(98.2 \%)$ & 17 (94.4\%) & $<0.05$ & 0.075 & $<0.05$ \\
\hline \multicolumn{2}{|c|}{ MS duration (years) } & - & $10.9(5.5-16.0)$ & $22.6(13.9-33.3)$ & - & $<0.01$ & - \\
\hline \multicolumn{2}{|l|}{ EDSS } & - & $2.0(1.0-3.0)$ & $6.0(4.4-7.0)$ & - & $<0.01$ & - \\
\hline \multicolumn{2}{|l|}{ MSSS } & - & $2.08(1.01-4.17)$ & $6.74(3.74-7.46)$ & - & $<0.01$ & - \\
\hline \multicolumn{2}{|l|}{$2 y-R R$} & - & $0.0(0.0-1.0)$ & $0.0(0.0-0.0)$ & - & $<0.01$ & - \\
\hline \multicolumn{2}{|l|}{ ARR } & - & $0.31(0.17-0.57)$ & $0.0(0-0.13)$ & - & $<0.01$ & - \\
\hline \multirow[t]{3}{*}{ DMT } & None & - & 27 & 18 & & $<0.01$ & - \\
\hline & IFN $\beta$ & - & 23 & 0 & & & \\
\hline & GA & - & 5 & 0 & & & \\
\hline
\end{tabular}

Values are expressed as mean \pm SD for parametric variables and as median (interquartile range) for nonparametric variables

$H C$ healthy controls, RRMS relapsing-remitting MS, PMS progressive MS, HCMV human cytomegalovirus, EBV Epstein-Barr virus, EDSS expanded disability status scale, MSSS Multiple Sclerosis Severity Score, $2 y-R R$ relapse rate in the previous 2 years, ARR annualized relapse rate, DMT disease-modifying therapy, IFN $\beta$ interferon- $\beta, G A$ glatiramer acetate

\section{Discussion}

In the present study, we provide data supporting that HCMV infection alters the phenotypic and function of B cells in MS, modulating the influence of IFN $\beta$ and reducing the proinflammatory $\mathrm{B}$ cell profile. These observations may contribute to understand the putative influence of this viral infection in MS, as suggested by previous studies describing a low risk for MS in HCMV seropositive cases [5, 6]. Although an epiphenomenon linked to the exposure to other environmental factors could not be excluded in the light of these observations, putative mechanisms of heterologous immunity between

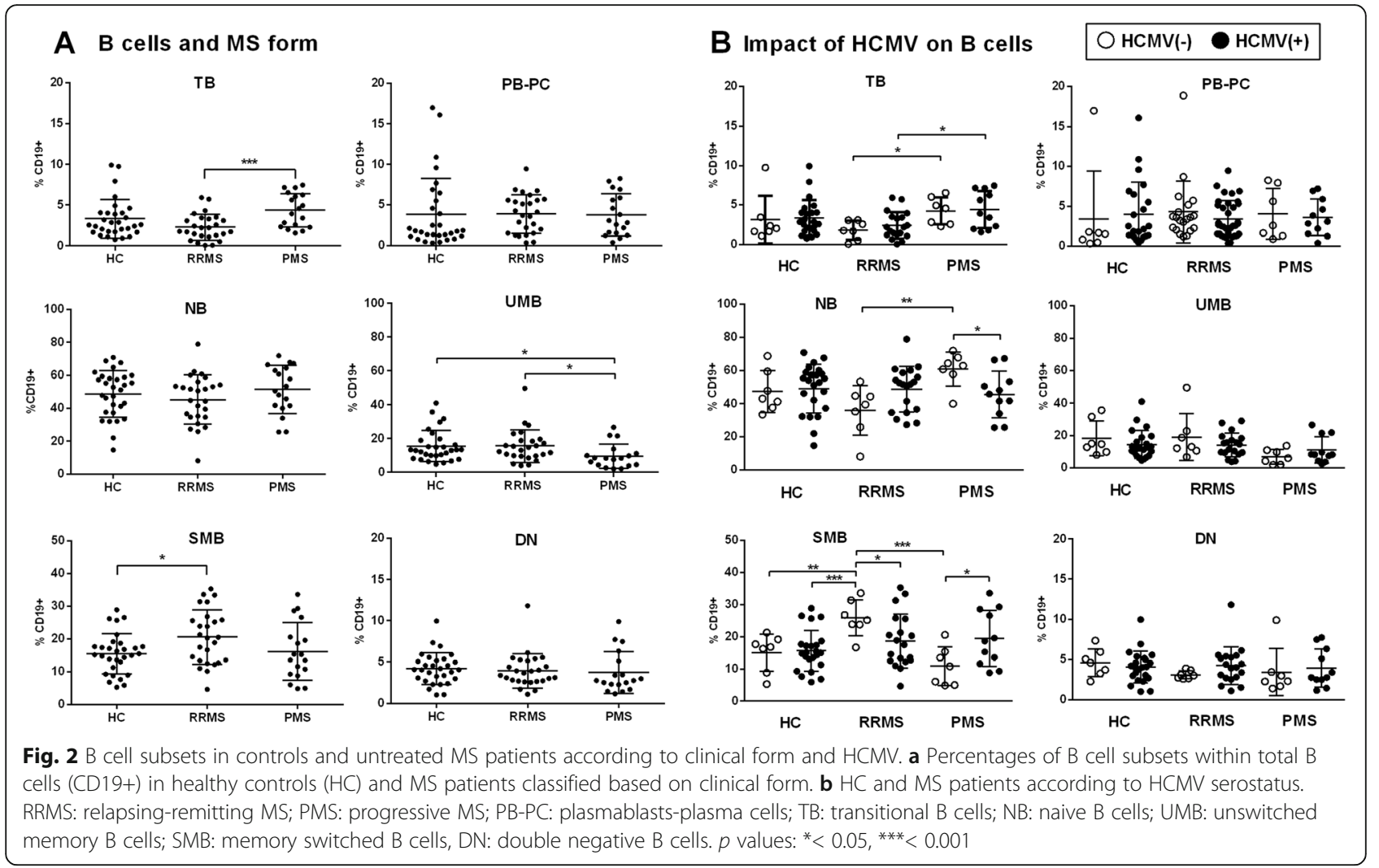




\section{A Influence of IFN $\beta$-therapy on B cells in MS}
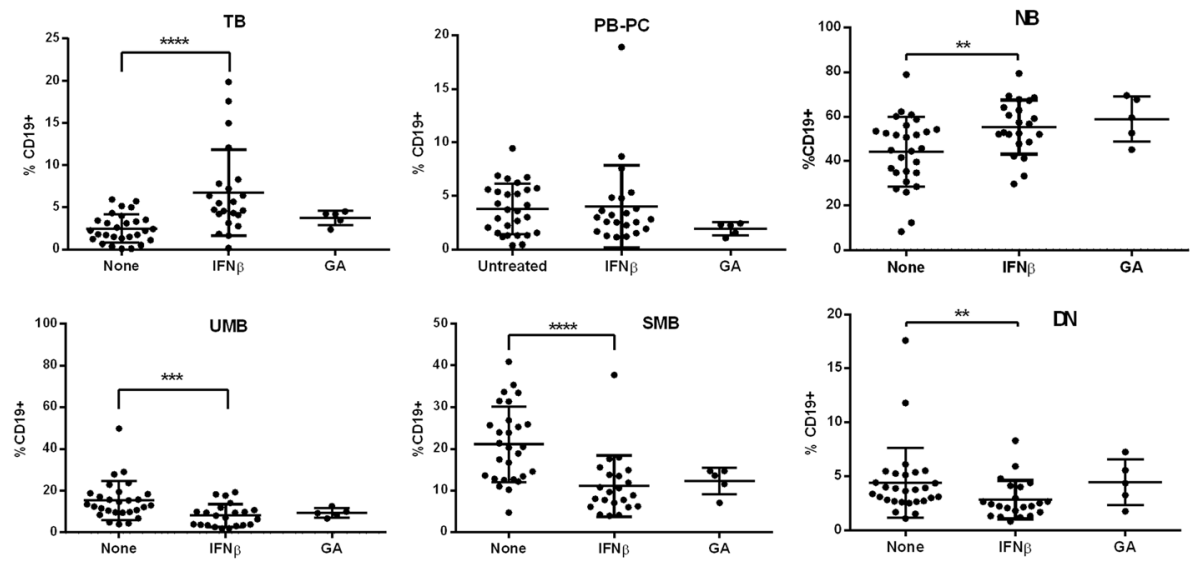

B Impact of HCMV serostatus on B cells from IFN $\beta$-treated MS patients
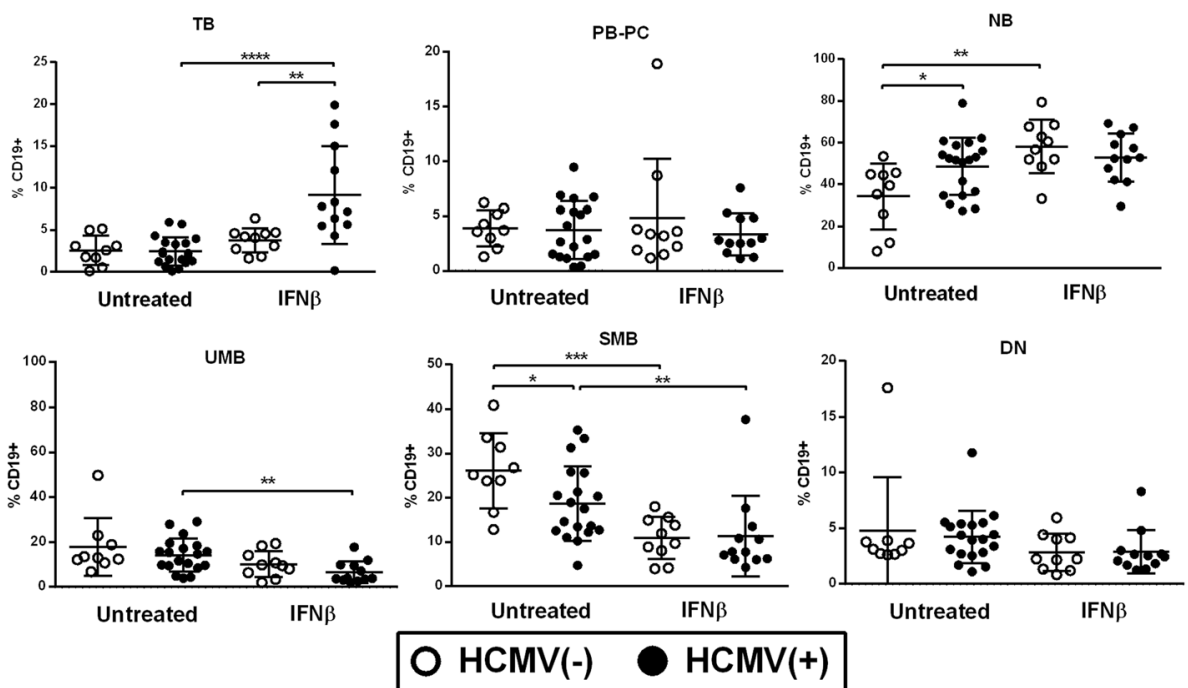

Fig. 3 Impact of HCMV on the B cell compartment in IFN $\beta$-treated MS patients. a B cell subsets in untreated $(n=27)$, IFN $\beta$-treated $(n=23)$, and glatiramer-acetate-treated $(n=5)$ RRMS patients. $\mathbf{b}$ Untreated and IFN $\beta$-treated MS patients classified based on HCMV serostatus. PB-PC: plasmablasts-plasma cells; TB: transitional B cells; NB: naive B cells; UMB: unswitched memory B cells; SMB: memory switched B cells; and DN: double negative B cells. $p$ values: ${ }^{*}<0.05,{ }^{* *}<0.01,{ }^{* * *}<0.001,{ }^{* * * *}<0.0001$

viruses [13-15] and HCMV-induced modifications on the immune system may be implicated in the effect of HCMV on MS $[7,8,16,17]$. In this regard, HCMV has been described as an environmental factor inducing striking effects on the immune system [7]. Nevertheless, in contrast to the well-known role of HCMV as a driving force behind the expansion of late-differentiated T lymphocytes $[8,18]$ and adaptive NK cells [9], the influence of chronic HCMV infection on B cells is minor and barely evaluated in previous studies.

B cells have been implicated in MS pathogenesis, with a special relevance of the memory subset $[2,19]$. Of note, no HCMV-related differences in B cell subsets between controls and MS patients were found in our study. However, an influence of the viral infection on the B cell subset distribution, namely the proportions of $\mathrm{NB}$ and $\mathrm{SMB}$, was perceived when MS form was considered, with an opposite effect in RRMS as compared to PMS patients. The reduced proportions of memory B cells observed in $\operatorname{HCMV}(+)$ RRMS appear consistent with a protective effect of the viral infection in MS described in previous studies $[5,6]$. Intriguingly, no influence of $\mathrm{HCMV}$ was detected in the B cell subset distribution in controls, in line with previous reports of minor HCMVinduced modifications in the $\mathrm{B}$ cell compartment as compared to $\mathrm{T}$ cells [18]. In this regard, HCMV-related differences in $\mathrm{B}$ cell subsets and the functional profile observed in our MS patients appeared uncoupled to markers of terminal differentiation of $\mathrm{T}$ cells and expansion of adaptive NKG2C+ NK cells (data not shown), 

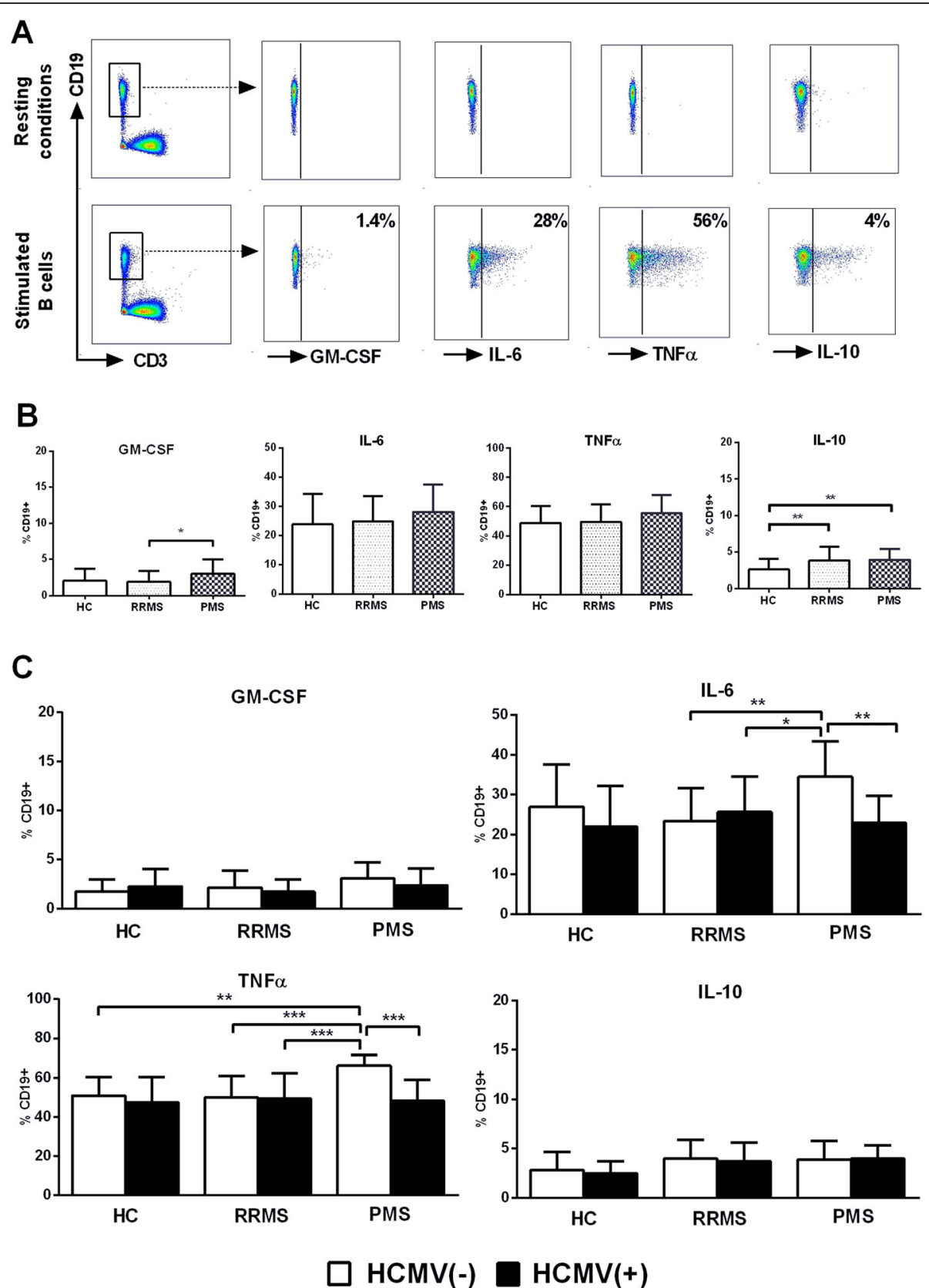

Fig. 4 B cell cytokine production in controls and MS patients. a Representative cases illustrating the gating strategy and staining of proinflammatory (GM-CSF, IL-6, TNFa) and anti-inflammatory cytokines (IL-10) in B cells in resting conditions and stimulated using CpG and PMA/ ionomycin. $\mathbf{b}$ B cell cytokine production in controls and MS patients according to MS clinical form. $\mathbf{c}$ Impact of HCMV on B cell cytokine production in controls and MS patients classified based on clinical form. $p$ values: ${ }^{*}<0.05,{ }^{* *}<0.01,{ }^{* * *}<0.001$

suggesting specific changes on the B cell compartment induced by HCMV in the setting of MS.

Of note, the shift in the B cell subset distribution associated with HCMV in our untreated MS patients was reminiscent of the impact of IFN $\beta$ therapy in HCMV seronegative RRMS patients, an effect that might be hypothetically related with interferon-signaling pathways induced by persistent HCMV infection [20]. In addition, the previously described increase of TB cells associated with IFN $\beta$ [12] was only observed in HCMV(+) RRMS patients. In view of the implications of $B$ cells in the mechanism of action of this cytokine [21], it is reasonable to hypothesize that HCMV infection in MS patients may modulate the influence of IFN $\beta$ on $B$ cell differentiation.

$\mathrm{B}$ cells in MS have been shown to display a proinflammatory cytokine profile $[22,23]$, which was also 
related with MS clinical form when B cells from CSF were evaluated in PMS cases [24]. In our study, B cells from $\mathrm{HCMV}(-)$ PMS patients displayed an enhanced pro-inflammatory profile as compared to $\operatorname{HCMV}(+)$ PMS cases, independently of other clinical variables. Although limited by the reduced sample size of PMS patients evaluated, these results suggest that persistent HCMV infection may reduce the inflammatory profile of B cells in MS, in line with previous reports describing differences in IL-10 production by B cells from monozygotic healthy twins discordant for HCMV [7].

\section{Conclusions}

Altogether, our study supports that HCMV infection modulates the distribution of $\mathrm{B}$ cell subsets and the IFN $\beta$ response in MS patients, and associated with a reduced pro-inflammatory cytokine profile in PMS, thus providing mechanistic insights on the putative beneficial influence of HCMV in MS. Further studies are required to assess whether HCMV may also modulate the immunological response to other MS therapies targeting B cells $[19,25]$.

\section{Supplementary information}

Supplementary information accompanies this paper at https://doi.org/10. 1186/s12974-020-01840-2.

Additional file 1: Table 1. Proportions of B cell subsets in controls and MS patients according to HCMV serostatus.

\section{Abbreviations}

EBV: Epstein-Barr virus; HCMV: Human cytomegalovirus; IFNB: Interferon-beta; MS: Multiple sclerosis; PBMCs: Peripheral blood mononuclear cells; PMS: Progressive multiple sclerosis; RRMS: Relapsing-remitting multiple sclerosis

\section{Acknowledgements}

Not applicable.

\section{Authors' contributions}

$A Z, A V, E A-P, A M$, and JM-R designed the study, executed experiments, and performed the statistical analysis. EM and ML contributed to the acquisition and analysis of data. AZ, EA-P, JY, ML-B, and JM-R contributed to interpretation of the results and wrote the final draft that was revised for all authors. ML-B and $J M-R$ contributed to data interpretation and critically reviewed the manuscript. The authors read and approved the final manuscript.

\section{Funding}

This work was supported by grants FIS/PI17/00254, SAF 2016-80363-C2-1-R (Spanish Ministry of Economy and Competitiveness and FEDER), the EU FP7 MINECO Infect-ERA Program (PCIN-2015-191-C02-01), and Red Española de Esclerosis Múltiple (REEM) from the Instituto de Salud Carlos III, the European Regional Development Fund (Grant RD16/0015/0011), and the Spanish Ministry of Economy and Competitiveness.

\section{Availability of data and materials}

The datasets used and/or analysed during the current study are available from the corresponding author on reasonable request.

\section{Ethics approval and consent to participate}

The study was approved by the local ethics committee (Hospital del Mar Research Institute, IMIM, ethic approval number: 2016/6607/I). Patients gave written informed consent to enter the study and provide peripheral blood samples.

\section{Consent for publication}

Not applicable.

\section{Competing interests}

A. Zabalza has received travel funding from Biogen Idec, Novartis, and Genzyme. A. Moreira has received travel funding from Teva, Biogen Idec, Novartis, Almirall, Bayer, and Genzyme, and personal fees for lectures from Genzyme. E. Munteis has received personal fees for consulting services and lectures from Merck-Serono, Biogen Idec, Teva, Genzyme, Novartis, Bayer, and Almirall. JE. Martínez-Rodríguez has participated as principal investigator in pharmaceutical company-sponsored clinical trials including Novartis, Roche, Merck-Serono, Actelion, and Celgene, and personal fees for consulting services and lectures from Novartis, Biogen Idec, and Merck-Serono. A Vera, E. AlariPahissa, J. Yélamos, M. Llop, and M. López-Botet declare that they have no competing interests.

\section{Author details}

${ }^{1}$ Neurology Department, Hospital del Mar Medical Research Institute (IMIM), Passeig Marítim, 25-29, 08003 Barcelona, Spain. 'Departament de Medicina, Universitat Autònoma de Barcelona, Barcelona, Spain. ${ }^{3}$ University Pompeu Fabra, Barcelona, Spain. ${ }^{4}$ Neurology Department, Althaia, Xarxa Assistencial i Universitària de Manresa, Manresa, Spain. ${ }^{5}$ Hospital del Mar Medical Research Institute (IMIM), Barcelona, Spain. ${ }^{6}$ Immunology laboratory, Hospital del Mar, Barcelona, Spain.

Received: 19 March 2020 Accepted: 11 May 2020

Published online: 20 May 2020

\section{References}

1. Hauser SL, Bar-Or A, Comi G, Giovannoni G, Hartung H-P, Hemmer B, et al. Ocrelizumab versus interferon beta-1a in relapsing multiple sclerosis. $\mathrm{N}$ Engl J Med. 2017;376:221-34

2. Li R, Patterson KR, Bar-Or A. Reassessing B cell contributions in multiple sclerosis. Nat Immunol. 2018;19:696-707.

3. Ascherio A, Munger KL, Lennette ET, Spiegelman D, Hernán MA, Olek MJ, et al. Epstein-Barr virus antibodies and risk of multiple sclerosis: a prospective study. JAMA. 2001;286:3083-8.

4. 't Hart BA, Jagessar SA, Haanstra K, Verschoor E, Laman JD, Kap YS. The primate EAE model points at EBV-infected $B$ cells as a preferential therapy target in multiple sclerosis. Front Immunol 2013:4:145.

5. Waubant E, Mowry EM, Krupp L, Chitnis T, Yeh EA, Kuntz N, et al. Common viruses associated with lower pediatric multiple sclerosis risk. Neurology. 2011;76:1989-95.

6. Sundqvist $E$, Bergström $T$, Daialhosein $H$, Nyström $M$, Sundström $P$, Hillert J, et al. Cytomegalovirus seropositivity is negatively associated with multiple sclerosis. Mult Scler J. 2014:20:165-73.

7. Brodin P, Jojic V, Gao T, Bhattacharya S, Angel CJL, Furman D, et al. Variation in the human immune system is largely driven by non-heritable influences. Cell. 2015;160:37-47.

8. Klenerman P, Oxenius A. T cell responses to cytomegalovirus. Nat Rev Immunol. 2016:16:367-77.

9. Gumá M, Angulo A, Vilches C, Gómez-Lozano N, Malats N, López-Botet M. Imprint of human cytomegalovirus infection on the NK cell receptor repertoire. Blood. 2004;104:3664-71

10. Martínez-Rodríguez JE, Cobo-Calvo A, Villar LM, Munteis E, Blanco Y, Rasal R, et al. Adaptive natural killer cell response to cytomegalovirus and disability progression in multiple sclerosis. Mult Scler. 2016;22:741-52.

11. Lublin FD, Reingold SC, Cohen JA, Cutter GR, Sorensen PS, Thompson AJ, et al. Defining the clinical course of multiple sclerosis: the 2013 revisions. Neurology. 2014;83:278-86.

12. Haas J, Bekeredjian-Ding I, Milkova M, Balint B, Schwarz A, Korporal M, et al. $B$ cells undergo unique compartmentalized redistribution in multiple sclerosis. J Autoimmun. 2011;37:289-99.

13. Welsh RM, Che JW, Brehm MA, Selin LK. Heterologous immunity between viruses. Immunol Rev. 2010;235:244-66.

14. White DW, Suzanne Beard R, Barton ES. Immune modulation during latent herpesvirus infection. Immunol Rev. 2012;245:189-208. 
15. López-Montañés M, Alari-Pahissa E, Sintes J, Martínez-Rodríguez JE, Muntasell A, López-Botet M. Antibody-dependent NK cell activation differentially targets EBV-infected cells in lytic cycle and bystander B lymphocytes bound to viral antigen-containing particles. J Immunol. 2017; 199:656-65.

16. Alari-Pahissa E, Moreira A, Zabalza A, Alvarez-Lafuente R, Munteis E, Vera A, et al. Low cytomegalovirus seroprevalence in early multiple sclerosis: a case for the 'hygiene hypothesis'? Eur J Neurol. 2018;25:925-33.

17. Moreira A, Alari-Pahissa E, Munteis E, Vera A, Zabalza A, Llop M, et al. Adaptive features of natural killer cells in multiple sclerosis. Front Immunol. 2019;10:2403.

18. Chidrawar S, Khan N, Wei W, McLarnon A, Smith N, Nayak L, et al. Cytomegalovirus-seropositivity has a profound influence on the magnitude of major lymphoid subsets within healthy individuals. Clin Exp Immunol. 2009:155:423-32.

19. Baker D, Marta M, Pryce G, Giovannoni G, Schmierer K. Memory B cells are major targets for effective immunotherapy in relapsing multiple sclerosis. EBioMedicine. 2017;16:41-50.

20. Lee $\mathrm{GC}$, Song $\mathrm{BH}$, Lee $\mathrm{CH}$. Increase in the expression of human leukocyte antigen class I in human fibroblasts by soluble factors secreted from human cytomegalovirus-infected cells. Mol Cells. 2001;11:392-8.

21. Schubert RD, Hu Y, Kumar G, Szeto S, Abraham P, Winderl J, et al. IFN- $\beta$ treatment requires $B$ cells for efficacy in neuroautoimmunity. J Immunol. 2015;194:2110-6.

22. Duddy M, Niino M, Adatia F, Hebert S, Freedman M, Atkins H, et al. Distinct effector cytokine profiles of memory and naive human B cell subsets and implication in multiple sclerosis. J Immunol. 2007;178:6092-9.

23. Bar-Or A, Fawaz L, Fan B, Darlington PJ, Rieger A, Ghorayeb C, et al. Abnormal B-cell cytokine responses a trigger of T-cell-mediated disease in MS? Ann Neurol. 2010;67:452-61.

24. Stein J, Xu Q, Jackson KC, Romm E, Wuest SC, Kosa P, et al. Intrathecal B cells in MS have significantly greater lymphangiogenic potential compared to B cells derived from non-MS subjects. Front Neurol. 2018:9:554.

25. Longbrake EE, Cross AH. Effect of multiple sclerosis disease-modifying therapies on B cells and humoral immunity. JAMA Neurol. 2016;73:219-25.

\section{Publisher's Note}

Springer Nature remains neutral with regard to jurisdictional claims in published maps and institutional affiliations.

Ready to submit your research? Choose BMC and benefit from:

- fast, convenient online submission

- thorough peer review by experienced researchers in your field

- rapid publication on acceptance

- support for research data, including large and complex data types

- gold Open Access which fosters wider collaboration and increased citations

- maximum visibility for your research: over $100 \mathrm{M}$ website views per year

At $\mathrm{BMC}$, research is always in progress.

Learn more biomedcentral.com/submissions 